\title{
ПРЕДБОЖИЋНИ И БОЖИЋНИ ОБИЧАЈИ СРБА, МАЂАРА И РУМУНА У ВОЈВОДИНИ
}

\begin{abstract}
Сажетак
У раду су приказани божићни обичаји Срба, Мађара и Румуна у општини Ковин. Циљ истраживања био је испитати сличности и разлике између божићних обичаја и ритуала код представника три различите етничке заједнице које живе на истом простору, као и промене у њиховом спровођењу које је донело време.

Кључне речи: обичаји, бадње вече, коринђаши, Божић

\section{Увод}

У овом раду биће приказане најважније карактеристике божићних обичаја Срба, Мађара и Румуна у општини Ковин, а који су прикупљени током мог теренског истраживања. Прикупљени подаци биће поређени са литературним подацима који се баве истом тематиком, односно божићним обичајима на подручју Војводине.
\end{abstract}

\section{Друштвено-историјски контекст општине Ковин}

Општина Ковин припада Јужнобанатском округу и броји десет насеља у свом склопу. У општини живи највећи број Срба, затим следе Мађари, Румуни и Роми. Иако је читава општина хетерогена у погледу националне припадности њеног становништва, поједина насеља 
су готово једнонационална. У Скореновцу Мађари чине преко деведесет одсто укупног становништва, док, с друге стране, у Мраморку живи највећи број Срба. Састав становништва се током бурне и дуге историје мењао, што је свакако оставило трага на обичаје и ритуале данашњег становништва. Након формирања Војне границе Аустрија ће поред Срба, којих је у јужном Банату већ било, на ове просторе населити велики број Немаца али и Румуна. Немци ће се са ових простора иселити након Другог светског рата, а доселиће се колонисти из околине Пријепоља и Нове Вароши.

У студији Слојеви народне религије у Банату Никола Ф. Павковић истиче два општа друштвено-политичка чиниоца неопходна за разумевање укупног народног живота и културе, па и слојевитости народне религије становника Баната (Павковић, 2009). Први чинилац јесте утицај цркве и државе на живот српског и румунског становништва у Банату, у периоду од 18. века па све до краја Првог светског рата. Формирање Војне границе и насељавање великог броја Немаца битно ће утицати на даљи развој Баната. Снажан процес присилне атеизације за време једнопартијског система Павковић истиче као други чинилац који ће значајно утицати на верски живот и целокупну традицијску културу. Доћи ће до потискивања, негативног вредновања и одбацивања највећег дела традицијске културе, а нарочито верских празника и обичаја (Павковић, 2010).

До обнове верског живота доћи ће осамдесетих година 20. века. Новија истраживања, међутим, показују дисконтинуитет у обнови верског живота, као и стварање нових ритуала и обичаја, о чему сведоче и теренски подаци.

\section{Комплекс божићних обичаја}

Годишњи обичаји везани су годишња доба, при чему у зимском периоду најзначајније место заузимају божићни празници. Њима претходе одређени празници у којима се већ неким елементима наговештава долазак Божића, а и у празницима који следе након Божића, појављују се неки празнични елементи који су карактерисали Божић (Босић, 1996). 
Циклус зимских односно новогодишњих празника обиловао је мноштвом ритуалних и магијских радњи усмерених на то да се обезбеде срећа и напредак породице, родна година и здравље стоке и живине. Ти обреди представљају, с једне стране остатке паганских обичаја, док се, са друге стране, у њима могу видети елементи хришћанске традиције (Босић, 1996). Божићни комплекс празника је најбројнији у годишњем циклусу обичаја. Литературни подаци бележе да божићни циклус празника почиње Божићним покладама (27. новембар) (Босић, 1996), док моји подаци са теренског истраживања показују да они почињу касније, прослављањем Светог Николе.

\section{Поређење предбожићних обичаја}

У предбожићне обичаје у српском народу спадају бројни празници као што су: Божићне покладе, Света Варвара, Материце, Очеви, Свети Игњат и Туциндан. Порекло ових обичаја сеже у дубоку прошлост и добро су литературно документовани (Босић, 1996). Са друге стране, подаци прикупљени из теренског истраживања не помињу готово ниједан предбожићни празник код Срба у новије време, док теренски подаци добијени од припадника румунске и мађарске националне мањине можемо видети да предбожићни празници и даље заузимају важно место у њиховим културама. Непомињање предбожићних празника код Срба самим тим је значајна новина. У литератури, почев од Вука Врчевића, Никољдан се помиње као један од три значајна свеца који се посебно славе. Врчевић је у својој монографији овако описао прославу Вариндана, Савиндана и Никољдана. „После поклада, народ свечано и највеселије прослави три заособна свеца, тј. Вариндан, Савиндан и Никољдан (4. 5. 6. Дек.) На вече Варива дне настави се над ватром највећи казан, у ком се вари свакога измјешаног жита којега у кући за шјеме имају." (Врчевић, 1883). Врчевић истиче да се по селима у те три ноћи не пева јер је уз пост забрањена песма, али готово да нема особе у народу која не зна измишљену песму посвећену овим трима свецима (Врчевић, 1883).

Теренски подаци показују да божићни обичаји код Мађара у Скореновцу, почињу већ 19. новембра, када је имендан Ержебет, а 
до Божића се обележава више имендана. За сваки од њих везани су посебни обичаји, веровања и ритуали. Имендан Католин је 25. новембра, а тада почиње велики пост који траје све до Божића. Карактеристично је то да се у време поста тј. Адвента не смеју одржавати игранке, весеља, свадбе. За овај дан везано је и магијско предсказање времена. Верује се да ако овог дана пада киша да ће за Божић бити мраза и снега. Адвент су четири недеље пред Божић, тј. време када се врше припреме за велики празник. Жене спремају кућу, а мушкарци почињу клање стоке, обично свиња. Затим, 30. новембра је имендан Андраш. На овај дан, као и на дан Св. Барабала (4. децембра) присутна су љубавна гатања. Обичај је да девојке 30. новембра посте и да те вечери под јастук ставе "украдени” део мушке одеће како би сањале за кога ће се удати. На дан Св. Барбала обичај је да девојке уберу грану неког воћа и да је држе на топлом месту. Верује се да ако грана процвета девојка ће се следеће године удати. Св. Никола односно Миклош је велики празник, поготово за децу и слави се 6. децембра. Према веровању, данас Миклош долази у цркву и тамо дели деци поклоне, док је раније долазио по кућама и само деци која су у претходној години била добра делио слаткише.

И код Срба је постојао сличан обичај, а забележио га је Вук у Првој и Петој књизи српских народних пјесама (Караџић Стефановић, 1891)

У Првој књизи, у Пјесмама божићним срећемо овакав опис Божић бате, уз напомену да се пева уочи Божића:

194.

Божић, Божић бата

На обоја врата

Носи киту злата

Да позлати врата

И обоја побоја.

На сличне предбожићне обичаје наилазимо код Чеха у Гају. Павковић бележи обичаје везане за дан Св. Луције, као и за дан када се слави Микулаш (Св. Никола). И код Чеха Микулаш долази у куће и дели слаткише само оној деци која су била добра током године (Павковић, 2009). 
Код Румуна у Ковину постојао је обичај да се на Светог Николу у кућу унесе грана јабуке. Грана се стављала изнад пећи у воду, тако да би до Божића процветала, а на Божић би се стављала поред божићног колача (Малуцков, 1985). Теренски подаци показују да је обичај постојао раније, али се након досељавања Немаца у те крајеве изгубио. Грану јабуке заменила је новогодишња јелка која представља католички обичај. Грана симболише цветање и почетак новог живота, те се и уноси у кућу како би од почетка нове календарске године све кренуло да цвета у кући.

Непомињање већине предбожићних празника код Срба јасно указује на промене које је донело модерно време. Временом је дошло до упрошћавања традиције, те је и велики број празника изгубивши своју функционалност нестао.

Код Мађара у Скореновцу највише предбожићних обичаја везано је за дан Св. Луције, 13. децембра. Једно од предвиђања овог дана је предвиђање плодности. Обичај је да се на тај дан у тањир или чашу стави семе жита које се залива све до Божића. У зависности колико жито порасте, верује се да ће кућа имати толико среће у наредној години, као и какав ће род бити у пољима. Од дана Св. Луције до Бадњег дана сваки дан сматра се као месец у години. Обичај је да се записује какво је време било ког дана и на основу тога се предвиђа какво ће време бити ког месеца наредне године. И овај обичај забележен је код Гајачких Чеха, али и у неким деловима Хрватске (Павковић, 2009).

Један од најстаријих обичаја, о коме постоје разна предања, везан је за тзв. Столичу Св. Луције. Почев од 13. децембра па све до Бадње вечери мушкарци су сваког дана склапали по један део те столице. Столицу су носили на поноћну мису како би пред крај мисе могли да стану на њу и виде да ли у цркви има вештица. Вештице су, по веровању, „припремљене” на то да их неко посматра, па су мушкарци морали да трче кући како их вештица не би стигла.

Веровање у вештице и друга натприродна бића распрострањено је у народној свести. Обичај Столице Св. Луције данас се не спроводи, али су интересантна предања која су и даље присутна у народу. Према речима једног од казивача, пре скоро сто година у Скореновцу умро је један младић под тајанственим околностима. Прича се и 
данас да је видео вештицу, да га је она преплашила и да није успео да стигне кући и умро је исте ноћи. Иако је од овог догађаја прошао готово читав век, одржавање овог предања у народу јасно говори да је и веровање у вештице дубоко укорењено. Вештице се у предањима појављују у поноћ, доносе несрећу и невољу ономе ко их види. Интересантно је да је обичаји Столице Св. Луције забележен и у северозападном делу Хрватске и неким деловима Славоније (Dragić, 2008).

Код Срба сличана веровања у вештице бележи Милан Ђ. Милићевић. Сељаци верују да ноћу свака нечастива сила има власт, те може наудити човеку који се у то време нађе ван куће. Нечастиве силе нарочиту моћ имају од Божића до Богојављења док трају некрштени дани. Чим петлови запевају авети и караконџуле остављају оног кога су целу ноћ мучиле. Милићевић наводи занимљив опис како се сељаци чувају од вештица: „Стога сељаци полазећи ноћу куд ван куће, мећу за појас по кору хлеба или соли, по главицу бела лука, или другу какву ствар као предохрану од сваке нечастиве силе." (Милићевић, 1984).

\section{Божићни празници и обичаји}

Бадњи дан прославља се 24. децембра по новом, односно, 6. јануара по старом календару. Сви казивачи наводе да ујутру на Бадњи дан отпочињу припреме. Спрема се све што ће бити потребно за Бадње вече и за сва три дана Божића. Чисти се и спрема кућа, обезбеђују се дрва за ложење, храна стоци, јер се по народном обичају у току божићних празника ништа не ради ни у кући, ни у дворишту, ни у стајама за стоку. По народном објашњењу кућа се не чисти да се не би ишчистила и срећа из ње. Веровање да се кућа не сме чистити свакако садржи и дубљи смисао. Чајкановић пише да тих дана предмете у кући окружују душе предака, те се кућа не сме чистити да се не би одагнале и очистиле присутне душе (Чајкановић, 1970). У литератури срећемо и забране изласка из куће на Бадњи дан и првог дана Божића (Босић, 1996). У прошлости се препоручивало да људи не излазе из куће на Бадње вече и на први дан Божића, па су зато унапред припремали све што им је било потребно тих дана за укућане и стоку, и тиме су се, према њиховом схватању чували од злих сила. У 
данашње време такав обичај нисмо забележили у нашем теренском истраживању. Али неки од обичаја које је забележио још Вук Врчевић присутни су и данас. Тако бележимо обичај паљења кандила испод иконе крсне славе. Одмах по повратку са гробља домаћин пали кандило и наставља са припремама за Божић. Обичај одласка на гробље задржао се до данас. Домаћин на гробље носи орахе, колаче и вино, а према казивачевим речима на гробље се одлази како би се позвали покојници да дођу на Божић (Врчевић, 1883).

Знатно више обичаја везаних за Бадњи дан чули смо од казивача који су причали о српским, односно румунским обичајима, него од казивача који су причали о слављењу Божића код Мађара. Интересантно је да се многи обичаји Срба и Румуна подударају, као што је прича о уношењу сламе, жртвовању животиња, тако и оне о прављењу божићног колача.

\section{Обредни хлебови}

За божићне празнике карактеристично је и прављење тзв. божићних хлебова или колача. Прављење божићних колача једна је од најважнијих давно устаљених обредних радњи, која се и данас верно одржава. Божићне колаче домаћица обавезно меси рано ујутру на Бадњи дан. Обредно пециво среће се код Срба и Румуна, док се код Мађара не помиње.

Код Румуна обредно пециво је славски колач који се прави од пшеничног брашна. Код Срба срећемо две врсте божићних колача. Први се меси рано ујутру на Бадњи дан и зове се „здравље”. „Здравље” се попрска пшеницом и ставља на под поред божићног колача, са којим се и једе првог дана Божића. Обред око колача „здравља” пропраћен је читањем молитве. Када се очита молитва свако од укућана треба да дарива колач. Овом хлебу се приписује велика магијска моћ. Стављање новца у сито поред колача означава напредак и срећу породице, а сви укућани морају јести колач како би током године били здрави (Босић, 1996).

Узимање великог божићног колача пешкиром обичај је забележен у Банату и Срему. Како се божићном колачу приписује велика 
магијска моћ, не сме се додиривати голим рукама, те се и пресецање колача врши тако што домаћин колач држи пешкиром. (Босић, 1996). У ранијим истраживањима у Банату и Срему забележено је украшавање колача деловима бесквасног теста. „Извођене су веома рељефне, често уметнички израђене фигуре.” (Босић, 1996). Данас на тај обичај не наилазимо. Приметна је жеља да се обичаји сачувају од заборава, али у борби са временом долази до упрошћавања, те сложенији ритуали нестају, а опстају само једноставнији. Неретко данас наилазимо и на све већи број домаћинстава у којима се уместо прављеног реже куповни божићни колач.

Поред великог божићног колача, важан обредни колач је чесница. Чесница се меси ујутру на Божић, тако што се вода доноси са извора, а меси се у посуди која је нова и купљена нарочито за тај дан. Пре него што се вода са извора сипа, у посуду се ставља метални новчић. У чесницу се стављају ораси, а у тренутку када домаћица стваља чесницу у рерну, домаћин обавезно пуца (Босић, 1996).

У неким крајевима Србије чесницу меси домаћи. Овај обичај, по Кулишићу, настао је одређеним друштвено-историјским условима и представља симболички траг тренутка кад је мушкарац преузимајући власт у породици постао и носилац обичаја који су првобитно припадали женама (Кулишић, 1953). Интересантно је да се овај обичај јавља у неким деловима Баната у којима има пуно колониста. У Мраморку га нисмо забележили, те можемо закључити да су се досељеници у овом случају асимиловали са аутохтоним становништвом и њиховим обичајем прављења чеснице.

Када је реч о хлебовима код Румуна, литературни подаци говоре само о постојању погаче и божићног колача (Малуцков, 1985). Погача се ломи за ручак, а колач се обично носи у цркву, ујутру на Божић, на богослужење. Свештеник га реже у крст и прелива црвеним вином.

\section{Бадње вече}

За Бадњу вечеру обавезна је посна храна. После вечере домаћин узима орахе и баца по угловима собе, почев од истока према западу, док остали укућани скачу и хватају те орахе. Интере- 
сантно је поредити казивачево објашњење ритуала бацања ораха и закључка до којег су дошли научници. Казивач то објашњава као шалу, насупрот научном схватању да дрво ораха има хтонични карактер, а плод ораха служи као храна демонима. Бацање ораха у углове собе по Чајкановићу значило је давање хране прецима. Ораси се то вече лупају и једу са медом, али се љуске и кости рибе не склањају са стола (Чајкановић, 1970). Примећујемо да је услед заборављања магијског својства обичаја, обичај сведен на дечју игру. Реч је о типичном поступку „снижавања”, „спуштања” обичаја у сферу дечјег фолклора. Овај поступак приметићемо и везано за друге обичаје, попут деце која коринђају, наспрам ранијих времена када су то чинили одрасли или положника који је данас такође дете.

Вечера се једе прстима, на столу не сме бити ни нож, ни виљушка, а исто важи и за божићни ручак, јер по веровању, овим ће се сачувати мир у кући и стајама за стоку. Занимљиво је да се овај обичај не помиње у другим деловима Баната везано за Божић, али је присутан у обичајима везаним за друге празнике (Босић, 1996).

Слична је трпеза и код Румуна, на којој се налазе риба и проја, а најчешће се пије ракија. Код Румуна вечера се поставља испод стола, на поду. Овај обичај забележила је М. Босић код Срба у Срему. Порекло овог обичаја она налази у општеиндоевропском обичају да се на гозбама за мртве једе са гроба, односно пода (Босић, 1996).

\section{Уношење бадњака и сламе у кућу}

Обичај уношења сламе присутан је и код Румуна и код Срба, док се код Мађара не помиње. Румунски казивач каже да је обичај уношења сламе аутентичан за Румуне, међутим, срећемо га и у казивању о српским обичајима. Истицање овог обичаја као аутентичног за Румуне указује нам на казивачеву тежњу да, присвајањем одређених симбола, учврсти и огради свој национални идентитет. Овим и сличним поступцима друга два казивача увиђамо битно место и значај традиција у одређењу националног идентитета. И у литератури је уношење сламе у кућу забележено као један од најважнијих обичаја на Бадњи дан (Малуцков, 1985). 
Један од новијих обичаја у Банату је и одлазак у шуму по бадњак. Бадњак је у неким деловима Баната био потпуно непознат, све до доласка колониста, који ће тај обичај донети у ове крајеве. Одлазак по бадњак је у директној вези са црквом, јер се у шуму одлази са попом, а паљење бадњака врши се у порти цркве. Тај обичај је постао део божићног ритуала пре двадесетак година, а видно је приметна и велика улога цркве у оживљавању тог обичаја.

Сличне податке, када је у питању бадњак, налазимо и у литератури. Никола Павковић истиче да је бадњак је данас у неким породицама непознат. Неједнак одонос према бадњаку вероватно проистиче из различитог порекла појединих фамилија. Данас група људи иде тракторским приколицама ван села по бадњак. Ову појаву Павковић одређује као нову и доводи је у директну везу са укидањем верских забрана деведесетих година 20. века. Паљење бадњака чини се уз сагласност и присуство свештеника. Старији људи то не одобравају, истиче Павковић. „Такве новотарије у обичајима и теорији фолклора познате су под именом фолклоризам и/или измишљање традиције, коју најчешће ствара друштвена елита. У случају бадњака долази до мењања и измештања обредно-религијске функције и учесника из изворног друштвеног и културног контекста." (Павковић, 2010).

\section{Коринђање}

У селима Јужног Баната задржао се обичај коринђања на Бадње вече како код Срба, тако и код Румуна и Мађара. Деца се организују по групама, иду од куће до куће и певају песме. Потом их домаћин награди јабукама, орасима, чоколадама и са нешто ситног новца.

Сазнајемо да се раније код Румуна у коринђање кретало у поноћ и да су коринђаши били само мушкарци, момци углавном, чланови црквеног хора. Деца су ишла у коринђање тек ујутру, на први дан Божића. До промене је дошло, сматра се, услед утицаја српских обичаја.

ИкодМађара наилазимо на готово идентичне обичаје коринђања. На Свето вече деца се скупљају и иду у групама по кућама и певају песмице о рођењу Исуса Христа, што се зове „опевавање”. Домаћица деци, после отпеване песме подели слаткише и нешто ситног новца. 
Није познато да деца из православних породица одлазе да коринђају у католичке домове, док се код Миле Босић у књизи Годишњи обичаји Срба у Војводини овај обичај често среће (Босић, 1996). Одсуство овог обичаја можемо тумачити све већом националном хомогеношћу места у којима су рађена теренска истраживања, у односу на ранија времена када су ова места била вишенационална. С друге стране, могући узрок изостанка ове појаве можемо тражити и у чињеници да се деца уче да певају божићне песме само на њиховом матерњем језику.

\section{Божић}

Божић се слави као дан Христовог рођења 25. децембра по новом, односно 7. јануара по старом календару. У народу се сматра највећим празником у години и слави се два дана. Први дан Божића је најважнији и најсвечаније се прославља. За први дан је везано и највише обредних радњи и веровања, било да се одвијају у кругу породице или су пак заједнички за читаву сеоску заједницу. Главни обичајни елементи првог дана Божића су доношење воде, мешање чеснице, долазак положајника (код Срба и Румуна), а заједнички обичај за све три културе јесте обредни божићни ручак (Босић, 1996).

\section{Доношење воде}

Доношење воде је један од главних обичаја првог дана Божића код Срба и Румуна. По воду одлази домаћин у зору на извора или до бунара по тзв. „божићну” воду. Домаћин носи у руци зрневље које је остало од Бадње вечере, са тим зрневљем посипа воду, потом узима воду и доноси је кући домаћици. Са том водом обавезно се меси чесница. У вези са обичајем доношења воде је и обичај куповине новог суда у кући. У тај нови суд домаћица ставља новчић, а кад домаћин донесе воду са извора онда се меси чесница.

Обреди везани за доношење воде и веровање у њену магијску моћ имају корене још у паганству. Многим изворима народ и данас 
приписује исцелитељску моћ. Ова народна схватања везују се за веровања да се око извора окупљају разна натприродна бића, која могу помоћи да укућани буду здрави, да поље добро роди итд. По Душану Бандићу, веровање да неначету воду треба захватити из бунара пре изласка сунца, проистиче из веровања у опасно магијско дејство сунца које, поред осталог, може утицати на раст усева и плодност поља (Бандић, 1980). Кулишић сматра да се по општем народном веровању, у извору или бунару налазе душе предака (Кулишић, 1970). Данас се вода сипа у кућама, а од старог начина мешања чеснице задржан је обичај куповине новог суда у којем ће се чесница умесити.

\section{Положник (полаженик)}

У Мраморку је забележен обичај положника. То су деца која ујутру иди по кућама, попут коринђаша који су ишли претходне вечери. Положионици добијају од домаћина кошуљу или пешкир. Као положника обично се прижељкују мушко дете, како би у тој кући било мушке и здраве деце. Интересантно је упоредити податке из литературе са нашим теренским подацима. Мила Босић у књизи Годишњи обичаји Срба у Војводини бележи да је обичај полажења кућа, односно долазак првог посетиоца у кућу на Божић, широко распрострањен у Војводини и то не само код Срба, већ и код осталих народа, првенствено Мађара (Босић, 1996). У нашим истраживањима, међутим, овај обичај забележен је код Срба у Мраморку, код Румуна се помиње одлазак деце код комишија на први дан Божића, али се не именује као полажање, а код Мађара овог обичаја нема.

\section{Божићни ручак}

Ручак је насвечанији тренутак Божића, када су сви чланови породице на окупу. Код Мађара је обичај да се за ручак спрема месо од неке пернате живине. Наиме, према веровању, тиме ће све што је 
лоше остати у тој години. Са друге стране, за дочек Нове године једе се прасе јер према народном веровању оно „њушком све гура напред и онда ће све бити добро." Ово је још једно од дубоко укорењених веровања у народу. Мила Босић овај веровање бележи и код Срба, у неким местима на северу Војводине (Босић, 1996).

Код Срба и Румуна домаћица, пре изношења јела на трпезу кади трпезу, а затим и јело. Кађењем се заштићује трпеза и кућа од невидљивих сила. Пре почетка ручка пали се свећа. У Мраморку се реже колач и приликом резања пева Рождество. С друге стране, код Румуна колач се ставља изрезан на сто, тај колач резан је у цркви, а сад га домаћин дели укућанима. Након ручка домаћин са чашом вина у дворишту наздравља целом домаћинству и стоци. Могуће је да је ово наздрављање заправо остатак некадашњег обичаја гледања у плећку. Врчевић је забележио како је положник након ручка гледао у плећку, док је остатак породице ишчекивао његово пророштво (Врчевић, 1883).

\section{Долазак коњаника и вијање Божића}

Овај обичај забележен је и у Мраморку и у Ковину. Код Срба у Мраморку коњаници долазе првог дана Божића, након ручка. То су младићи које домаћин пушта у двориште и служи их најчешће црвеним вином јер оно симболише Исусову крв. По веровању коњаници долазе да виде где је Христ.

Код Румуна, долазак коњаника је у вези са обичајем вијања или истеривања Божића. Младићи у току поподнева јашу коње, певају здравице, обилазе куће и свима желе срећне празнике. Истеривање Божића представља призивање лепших дана и терање свега што је било лоше у претходној години.

Слични обичаји везују се и за покладе. Покладе представљају последњи дан или последњу недељу пред вишенедељни пост. Прослављају се весело и бучно, са обиљем мрсне хране. У народној традицији највише је обележаван дан пред велики ускршњи пост.У речнику Словенске митологији наилазимо на обичаје који се спро- 
воде о покладама. „Код балканских Словена за последњи дан пред ускршњи пост карактеристичне су рођачке посете (међусобно праштање грехова и увреда), гатања за истеривање болести и нечистих сила." (Толстој, 2001).

У Мраморку се вијање Божића одвија трећег дана и то ради домаћица. Истеривање буба, мишева, змија својеврсно је призивање пролећа и лепших дана, а обичај је и настао утицајем обичаја из пролећног циклуса.

Обичај доласка коњаника познат је и у литератури и уз незнатне разлике спроводи се у селима Баната, Бачке и Срема. У Чуругу се јахачи маскирају и тако обилазе куће, што опет можемо довести у везу са покладним обичајем маскирања и обиласка кућа (Босић, 1996).

\section{Игра „хусара”}

И Код Мађара у Скореновцу постоје обичаји који се спроводе првих дана Божића. На први дан Божића постоје још један обичај који се и данас спроводи. Тај обичај јесте опевавање девојака или игра „хусара.” Он подразумева игру у којој младић иде од куће до куће, али улази само у оне куће у којима живе девојке. Након што их домаћин угости, младић пева песму о рођењу Исуса Христа, након чега улазе два Хусара, тј. војника са мачевима који рецитују шаљиве песме.

\section{Закључак}

Поређење сродних културних појава у животима припадника различитих етничких заједница које живе на истом тлу постављен је као један од циљева нашег рада. Осим тога, циљ рада био је да се утврде, у оној мери у којој то грађа дозвољава, промене настале у садржају празновања, али и значај који су божићни празници имали у ранијем периоду и који имају у садашњим условима.

Како је у уводу напоменуто друштвено - историјске промене које су се одиграле у другој половини 20. века утицале су и на народ- 
ни живот и обичаје. Током деведесетих година двадесетог века традиционална пракса ће под утицајем цркве оживети, али на нешто другачији начин. Тако ће се у Мраморку по бадњак ићи са попом, док ће Румуни из Ковина божићни колач сећи у цркви. С друге стране, снажан процес модернизације друштва захватио је све области живљења, те је свој одраз добио и у обичајима и веровањима становника општине Ковин.

Поставља се питање у којој мери је ова врста традиционалне културе, којом смо се ми бавили захваћена таласом промена. Тако је примећено да су вишедневни празници значајно редуковани. Теренски подаци говоре о изостављању или успутном помињању прича о великом божићном посту и другим предбожићним празницима. Предбожићним обичајима код Срба придаје се знатно мање пажње у односу на ранија времена. Готово да је потпуно нестао обичај прославе Вариндана, Материца и Очева, а изостаје и прича о божићним покладама. Колико и у којој мери се поштује божићни пост нисмо чули од наших казивача. Сви они истичу да је за Бадњи дан обавезна посна храна, док се велики божићни пост само успутно помиње.

Време за обављање појединих обичајних радњи се помера, пошто се прилагођава обавезама које имају извршиоци обичајних радњи. Примећује се много више флексибилности у обављању радњи, него што је то било раније. Када је реч о простору, поред саме куће, црква постаје значајно место где се изводе обичаји.

Промене у начину живота довеле су и до замена појединих делова обичаја. Тако ће уместо пуцања из пушке домаћин бацити петарду кад домаћица стави чесницу у рерну, а уместо одласка по воду на извор, домаћица сипа воду у кући.

Процеси модернизације и урбанизације веома доприносе промени традиционалне културе. Приметно је и да се елементи старије обредне и обичајне праксе мешају са новијима. Уочено је, такође, и заборављање или потпуни нестанак сложенијих радњи и обреда, док се једноставнији поступци и обичаји и данас одржавају, али уз видно „снижавање”, „спуштање” обичаја у сферу дечјег фолклора. Главну улогу у већини обредних радњи уместо одраслих данас имају деца. Када је реч о магијско-религијској функицији обичаја, она је у 
савременом моделу изгубљена. Поједине магијске радње се и даље одржавају, али се њихово значење не зна објаснити или се објашњава као игра и шала.

Када је реч о међусобним утицајима, примећујемо утицај српских обичаја коринђања на румунске. Временом су Румуни прихватили српски обичај те у коринђање више не иду одрасли момци у поноћ, већ деца, након бадње вечере. Утицај католичких обичаја на православне огледа се у кићењу јелке, која је у румунским домовима заменила грану јабуке, а у српским кићење бадњака црвеном свилом и гранчицом маслине.

Заједничке одлике за три народа могу се пронаћи у трепезама за Бадње вече и божићни ручак. Сва три казивача истаћи ће обавезно посну бадњу вечеру, као и обилну и богату трпезу за божићни ручак. Различите врсте обредних хлебова помињу се само код Срба и Румуна. Ова два народа имаће и друге исте или сличне обичаје везане за уношење сламе у кућу, доношење воде са извора, првог госта у кући на Божић, као и обичаје везане за други дан Божића.

На основу наших истраживања можемо закључити да божићни обичаји и данас заузимју важну улогу у свакодневном животу становника општине Ковин. Божић се прославља у кругу породице и представља један од најзначајних и најсвечанијих годишњих празника.

\section{Литература}

Бандић, Д. (1980). Табу у тадиционалној култури Срба. Београд, Србија: БИГЗ.

Босић, М. (1996). Годишњи обичаји Срба у Војводини. Нови Сад, Србија: Прометеј. Врчевић, В. (1883). Три главне народне свечаности: Божић, крсно име и свадба. Панчево: Књижара браће Јовановић.

Dragić, M. (2008). Advent u liturgiji i narodnoj kukturi Hrvata. Crkva u svijetu, 43(3), 414-440.

Кулишић, Ш. (1953). Поријекло и значење божићног обредног хљеба у Јужних Словена. Сарајево, СФРЈ: ГЗМ у Сарајеву Н.С.

Кулишић, Ш., Петровић, П. Ж., Пантелић, Н. (1970). Српски митолошки речник. Београд, Србија: Нолит.

Малуцков, М. (1985). Румуни у Банату-етнолошка монографија. Нови Сад, Србија: Војвођански музеј Нови Сад. 
Милићевић, М.Ђ. (1984). Живот Срба сељак. Београд, Србија: Просвета

Павковић, Н.Ф. (2009). Банатско село, друштвене и културне промене Гаја и Дубовца. Нови Сад, Србија: Матица српска

Павковић, Н.Ф. (2010). Банат кроз векове, слојеви култура Баната. У: М. Матицки,

В. Јовић (уредници), Слојеви народне религије, зборник радова (стр. 548). Београд: Вукова задужбина.

Чајкановић, В. (1970). Мит и религија у Срба. Београд, Србија: СКЗ.

Толстој, С.М., Раденковић, Љ. (2001). Словенска митологија-енциклопедијски речник. Београд, Србија: Zepter Book World

Караџић Стефановић В. (1891). Српске народне пјесме, Књига прва. Биоград, Србија: Штампарија Краљевине Србије

\title{
Jovana Nikolić
}

\section{BEFORE CHRISTMAS AND CHRISTMAS TRADITIONS OF SERBS, HUNGARIAN AND ROMANIANS IN VOJVODINA}

\begin{abstract}
Summary
This paper presents the Christmas traditions of Serbs, Hungarians and Romanians in the municipality Kovin. The aim of the research was to examine the similarities and differences between Christmas traditions and rituals with representatives of three different ethnic communities living in the same area, as well as changes in their implementation that brought time.
\end{abstract}

Key words: traditions, Christmas Eve, korinđaši, Christmas 